\title{
Physico-Chemical Parameters and Seasonal Variation of Zooplankton in Song River at Gularghati of Dehradun, Uttarakhand
}

\author{
J.V.S. Rauthan ${ }^{1^{*}} \cdot$ Sangeeta Rawat $^{2} \cdot$ Gopal Chhetri $^{\mathbf{3}}$ \\ ${ }^{I}$ Department of Zoology, D.A.V. J(P.G.) College, Dehradun. \\ ${ }^{2}$ Department of Zoology, Govt. Degree College, Doiwala \\ ${ }^{3}$ Department of Chemistry, D.A.V. (P.G.) College, Dehradun
}

*Coresponding author: drjvsrauthanji@gmail.com

Received: 21.10.2021; Revised: 17.12.2021; Accepted 19.12.2021

(C)Society for Himalayan Action Research and Development

\begin{abstract}
The present study is carried out during the period of January, 2020 to December, 2020 to investigate seasonal variation of the zooplankton in Song river, Gularghati, District Dehradun. During study period total 22 zooplankton species were found belonging to different groups. Protozoa consist of 8 species, rotifera consist of 7 species, copepoda consist of 5 species and two species of ostrocoda. The number of zooplankton was highest in summer season followed by winter and monsoon season.
\end{abstract}

Keywords: Zooplankton, Physico-chemical parameters, Song river.

\section{Introduction}

Plankton are organisms drifting in oceans, seas, and bodies of fresh water. The word zooplankton is derived from the Greek zoon, meaning "animal", and planktos, meaning "wanderer". Plankton is composed of the phytoplankton (the plants of the sea) and zooplankton (Zoh plankton) which are typically the tiny animals, found near the surface in aquatic environments. Like phytoplankton, zooplankton are usually weak swimmers and usually just drift along with the currents. Zooplanktons play important role in food web and food chain of aquatic habitat. Zooplankton is connecting like between autotrophs and heterotrophs in freshwater ecosystem. Zooplanktons are bioindicators in detecting the health and trophic status of aquatic bodies (Dede and Deshmukh, 2015). The zooplankton are useful indicator of aquatic community structuring and water condition. Therefore, the present study deals with the seasonal variation of zooplankton in Song river near Gularghati in Doon Valley.

\section{Materials and Methods}

(i) Study Area: Song river is a spring fed river originated from different small rivulets of the mountainous streams flowing downwards towards Doon Valley basins and finally it assimilates into river Ganga at Raiwala. The river Song is located at $30^{\circ} 28^{\prime}$ latitude and $78^{\circ}$ 08' longitude, with which peoples of the Maldevta, Gularghati, Lacchiwala, Doiwala, Chhiderwala, Nepali farm and Raiwala are very attached because this river is the only ultimate source of water for them travelling a total distance of approximately $42.5 \mathrm{~km}$. It merges into river Ganga at $78^{\circ} 48^{\prime}$ longitude and $30^{\circ} 2^{\prime}$ latitude after crossing Satyanarayana area in 
Raiwala. Therefore, in present study of the Song river its zooplankton and physico-chemical characteristics viz. temperature, velocity, total solids, total suspended solids, total dissolved solids, turbidity, $\mathrm{pH}$, dissolved oxygen, free $\mathrm{CO}_{2}$, BOD, COD, alkalinity, chlorides and sulphate.

\section{(ii) Sample collections and Biological}

Analysis: The present study was conducted for the period of one year from January, 2019 to December, 2019. The water samples were collected monthly between 7 AM to 11 AM. The data was articulated seasonally as summer, winter and monsoon. The plankton samples were collected through 50 litres of water by standard plankton net made up of bolting silk cloth No. 20 and the collected samples were fixed in $4 \%$ formalin. The zooplankton are identified with the help of standard literature up to generic level by using standard keys of Edmondson (1959), Dhanapathi (2000). The qualitative and quantitative analysis of the organism is carried out by Sedgwick rafter cell as standard per the methods (APHA, 1998, Khanna \& Bhutani, 2004).

\section{Result and Discussion}

The result of seasonal variation of physicochemical and zooplankton of Song river near Gularghati are illustrated in Table 1 and 2 . Species richness was high in summer and winter and it was minimum during monsoon. In present study number of protozoan was highest (94.69 \pm 62.63 unit / litre) in summer season and lowest
(71.85 \pm 54.31 unit / litre) in monsoon. The number of rotifera recorded highest $(88.09 \pm$ $50.58)$ in summer and lowest $(71.96 \pm 47.72)$ in monsoon. The copepoda and ostracoda have same pattern. Zooplankton is the intermediate link between phytoplankton and fish, which are the secondary producers in the aquatic environment.

In river Song, Gularghati dverse taxonomic groups of zooplankton representing protozoa, rotifera, copepoda and ostracoda were found during the course of study. In present investigation among zooplankton protozoa are single celled eukaryotes that community show characteristics usually associated with animals, most notably mobility and heterotrophy. Protozoa was maximum (94.69) in the summer and minimum (71.85) was found in monsoon. Similar study were made by Sunkad and Patil (2004), Mahajan (1981) and Khanna et al. (2012). Rotifers are the microscopic faunal component living mostly in fresh water, are characterized by the presence of an anterior wheel like rotating structure called corona. The rotifers are being considered as the most important soft bodied invertebrates. Rotifers was found to be highest (77.85) in summer and lowest (71.95) in monsoon. Similar observations were made by Sinha (1992). Pandey et al. (2004) also found similar result during the study of river Ramjan in Bihar. Copepod are groups of small crustaceans found in the nearly every fresh water habitat. A copepod was maximum (60.26 
unit/l) in summer and minimum (51.02 unit/l) in monsoon. Similar trend was noticed by Chauhan (1993) and Kaushal and Sharma (2007) in Renuka lake (H.P.). Ostracods are bivalve and have shape like small seeds. This inhabit in all kinds of freshwater and marine environments. The freshwater ostracods occur in kales, pools, swamps, streams and even in polluted waters (Khanna et al., 2007). The abundance of these provides a good food for aquatic organisms. At sampling site ostracods species was recorded in their optimum peak during summer (21.65 unit/l) and lowest peak (19.09 unit / 1) during summer. Similar observations were also made by Sunkad and Patil (2011) and Ishaq and Khan (2013) in Tons and Asan rivers in Dehradun district.

The physico-chemical parameters obtained during the period are tabulated in table-1. In the Song river at Gularghati, a difference in the fluctuation of water temperature was observed maximum $\left(28.2^{\circ} \mathrm{C}\right)$ in summer and lowest in winter $\left(18.6^{\circ} \mathrm{C}\right)$. The water temperature showed an upward trend from winter season to summer season. A more or less similar trend has been recorded in Song river at Dehradun by Khanna et. al. (2007). The velocity started to increase after winter season. The maximum $(0.94 \mathrm{~m} / \mathrm{sec})$ was recorded in monsoon and minimum $(0.72$ $\mathrm{m} / \mathrm{sec}$ ) in winter season. In the present investigation, it has been recorded that the velocity and the Total solids showed positive relationship. Maximum concentration (340.6 $\mathrm{mg} / \mathrm{l}$ ) of Total solid was found during monsoon which may be due to soil erosion or side cutting caused by the mainstream and minimum (240.0 $\mathrm{mg} / \mathrm{l})$ in winter. During the study, TDS was found minimum $(281.2 \mathrm{mg} / \mathrm{l})$ in winter and maximum $(360.4 \mathrm{mg} / \mathrm{l})$ in monsoon and increased value were probably due to heavy rain causing soil erosion and adding more suspended or dissolved solids from the nearby area

Table 1 : Seasonal variations of Physico-chemical Parameters of Song River at Gularghat, Dehradun

\begin{tabular}{lcccc}
\hline Parameters & Summer & Monsoon & Winter & Average \\
\hline Temperature $\left({ }^{\circ} \mathrm{C}\right)$ & 28.2 & 21.20 & 18.60 & 22.66 \\
Velocity $(\mathrm{m} / \mathrm{sec})$ & 0.82 & 0.94 & 0.72 & 0.82 \\
Total solids $(\mathrm{mg} / \mathrm{l})$ & 280.0 & 340.60 & 240.60 & 287.06 \\
T.D.S. $(\mathrm{mg} / \mathrm{l})$ & 270.0 & 360.40 & 281.20 & 303.86 \\
T.S.S. $(\mathrm{mg} / \mathrm{l})$ & 16.30 & 15.33 & 30.20 & 20.61 \\
Turbidity $(\mathrm{JTU})$ & 14.30 & 20.20 & 12.41 & 15.63 \\
pH & 7.90 & 6.90 & 8.40 & 7.73 \\
D.O. $(\mathrm{mg} / \mathrm{l})$ & 8.20 & 7.90 & 9.20 & 8.43 \\
B.O.D. $(\mathrm{mg} / \mathrm{l})$ & 2.21 & 2.43 & 3.40 & 2.68 \\
C.O.D. $(\mathrm{mg} / \mathrm{l})$ & 2.20 & 2.58 & 2.12 & 2.30 \\
Free $\mathrm{CO}_{2}(\mathrm{mg} / \mathrm{l})$ & 2.12 & 3.30 & 2.26 & 2.56 \\
Sulphate $(\mathrm{mg} / \mathrm{l})$ & 2.60 & 1.27 & 1.39 & 1.75 \\
Chloride $(\mathrm{mg} / \mathrm{l})$ & 23.36 & 20.92 & 17.24 & 21.50 \\
Alkalinity $(\mathrm{mg} / \mathrm{l})$ & 160.61 & 140.21 & 141.24 & 147.35
\end{tabular}




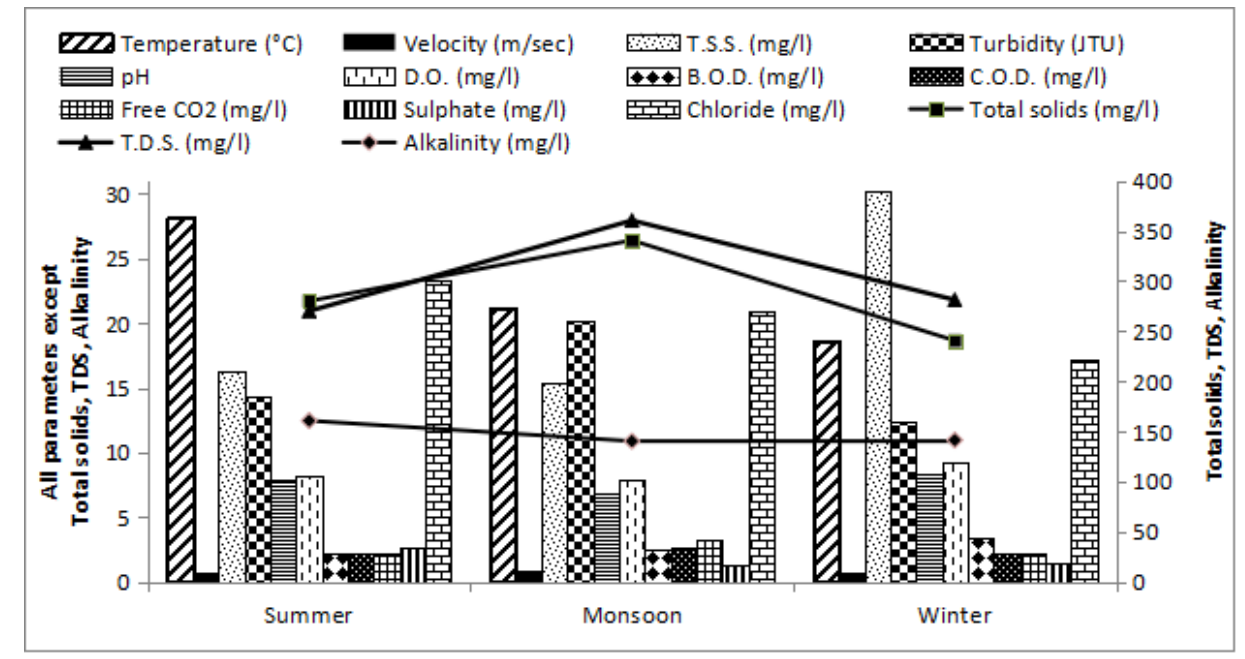

Fig. 1 : Seasonal variations of Physico-chemical Parameters of Song River at

Gularghat, Dehradun

Table 2 : Qualitative and Quantitative Distribution of Zooplankton (Unit/l) in River Song at Gularghati

\begin{tabular}{|l|l|l|l|}
\hline Zooplankton & Summer & Monsoon & Winter \\
\hline 1. Protozoa & $13.60 \pm 9.80$ & $10.88 \pm 7.70$ & $12.63 \pm 6.79$ \\
(i) Euglena & $14.60 \pm 10.21$ & $11.42 \pm 9.90$ & $12.20 \pm 8.80$ \\
(ii) Paramecium & $10.60 \pm 7.50$ & $7.75 \pm 6.00$ & $8.66 \pm 7.35$ \\
(iii) Peridinium & $8.60 \pm 7.22$ & $5.40 \pm 5.00$ & $6.90 \pm 6.30$ \\
(iv) Campanella & $10.55 \pm 6.80$ & $7.79 \pm 7.70$ & $8.93 \pm 7.79$ \\
(v) Epistylis & $12.20 \pm 8.21$ & $8.90 \pm 7.00$ & $9.90 \pm 6.50$ \\
(vi) Vorticella & $12.30 \pm 7.40$ & $9.90 \pm 6.60$ & $10.66 \pm 7.30$ \\
(vii) Arcella & $12.24 \pm 5.51$ & $9.81 \pm 4.41$ & $9.00 \pm 3.65$ \\
(viii) Difflugia & $\mathbf{9 4 . 6 9} \pm \mathbf{6 2 . 6 3}$ & $\mathbf{7 1 . 8 5} \pm \mathbf{5 4 . 3 1}$ & $\mathbf{7 8 . 8 8} \pm \mathbf{5 4 . 1 8}$ \\
\hline Total & $12.21 \pm 8.04$ & $9.36 \pm 7.77$ & $11.60 \pm 9.25$ \\
\hline 2. Rotifera & $14.62 \pm 8.76$ & $10.25 \pm 7.00$ & $11.79 \pm 7.78$ \\
(i) Keratella & $12.41 \pm 7.31$ & $11.60 \pm 6.35$ & $12.66 \pm 6.30$ \\
(ii) Nolthoca & $12.15 \pm 7.41$ & $9.90 \pm 6.30$ & $10.35 \pm 7.00$ \\
(iii) Rotatoria & $13.60 \pm 6.25$ & $10.25 \pm 7.00$ & $9.00 \pm 6.30$ \\
(iv) Ascomorpha & $11.10 \pm 6.28$ & $10.70 \pm 7.05$ & $11.60 \pm 8.80$ \\
(v) Trichocera & $12.00 \pm 6.53$ & $9.90 \pm 6.25$ & $12.70 \pm 7.20$ \\
(vi) Asplanchna & & & \\
(vii) Brachionus & & & \\
\hline
\end{tabular}




\begin{tabular}{|l|l|l|l|}
\hline Total & $\mathbf{8 8 . 0 9} \pm \mathbf{5 0 . 5 8}$ & $\mathbf{7 1 . 9 6} \pm \mathbf{4 7 . 7 2}$ & $\mathbf{7 9 . 7 0} \pm \mathbf{5 2 . 6 3}$ \\
\hline 3. Copepoda & & & \\
(i) Cyclops & $12.41 \pm 6.60$ & $11.12 \pm 5.60$ & $11.00 \pm 6.30$ \\
(ii) Daphnia & $12.59 \pm 6.38$ & $10.60 \pm 6.35$ & $12.70 \pm 7.79$ \\
(iii) Bosmina & $11.66 \pm 8.00$ & $9.35 \pm 7.26$ & $10.65 \pm 6.30$ \\
(iv) Helobdella & $10.00 \pm 6.00$ & $10.00 \pm 7.00$ & $11.41 \pm 6.15$ \\
(v) Nauplius & $13.60 \pm 5.89$ & $9.95 \pm 6.35$ & $12.51 \pm 7.60$ \\
\hline Total & $\mathbf{6 0 . 2 6} \pm \mathbf{3 2 . 8 7}$ & $\mathbf{5 1 . 0 2} \pm \mathbf{3 2 . 5 6}$ & $\mathbf{4 5 . 5 7} \pm \mathbf{3 4 . 1 4}$ \\
\hline 4. Ostracoda & & & \\
(i) Cypris & $12.70 \pm 7.20$ & $11.30 \pm 6.51$ & $12.00 \pm 8.00$ \\
(ii) Stenocypris & $8.55 \pm 6.35$ & $7.79 \pm 5.51$ & $9.25 \pm 6.30$ \\
\hline Total & $\mathbf{2 1 . 6 5} \pm \mathbf{1 3 . 5 5}$ & $\mathbf{1 9 . 0 9} \pm \mathbf{1 2 . 0 2}$ & $\mathbf{2 1 . 2 5} \pm \mathbf{1 4 . 3 0}$ \\
\hline
\end{tabular}

During present investigation, it was found that turbidity was higher (20.20 JTU) during monsoon and lower (12.41 in winter season. Similar results were also obtained by Khanna
(1993) and Joshi and Bisht (1993). The turbidity and Total solids work closely interrelated with one another and cause an effect upon the river and aquatic life.

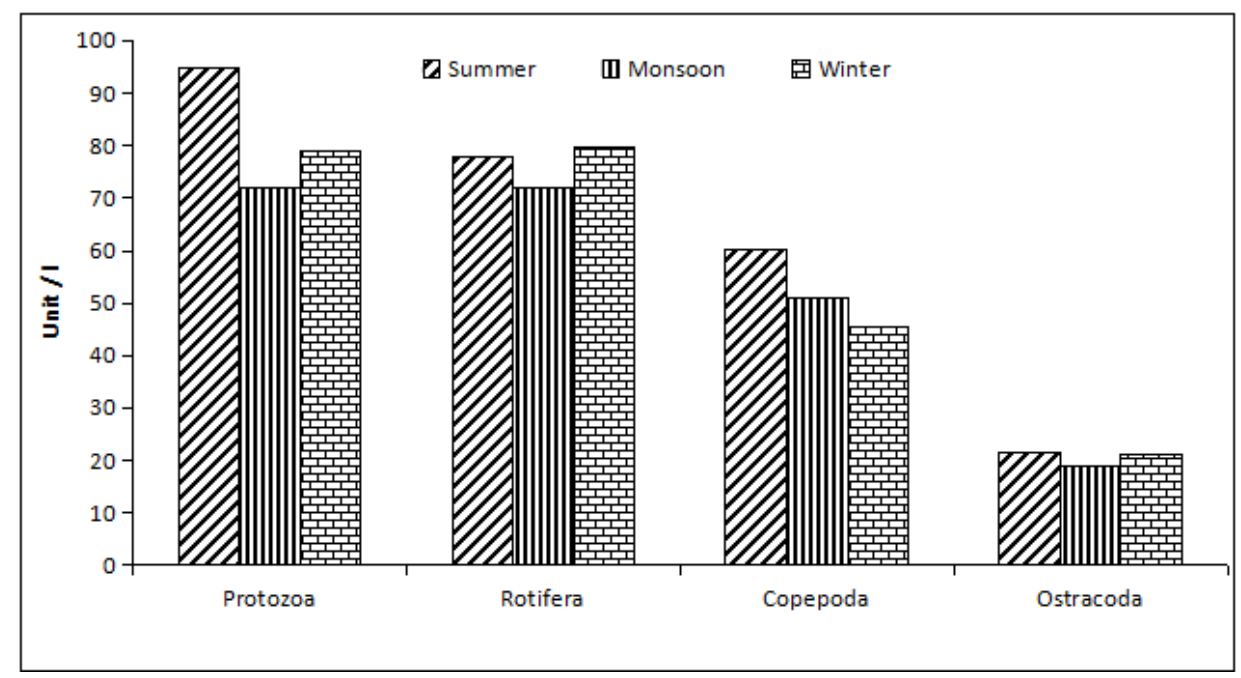

Fig. 2: Qualitative and Quantitative Distribution of Zooplankton (Unit/l) in River Song at Gularghati

The maximum $\mathrm{pH}$ (8.4) was recorded in winter months which might be due to increased chemical load in the river and due to increased photosynthetic activities and low dilution capacity of $\mathrm{pH}$ (6.9) was recorded in monsoon which was due to decrease in photosynthetic activities which was due to increase in turbidity affecting the penetration of light. Similar 
observations were reported by Badola and Singh (1981) and Sangu and Sharma (1985). Dissolved oxygen is usually related to ambient temperature, current velocity, rainfall and turbulence besides some biological components viz. planktonic blooms. Higher value $(9.20 \mathrm{mg} / \mathrm{l})$ of D.O. observed during winter months which permit retention of higher amount of air at lower temperature. Thus, low temperature has high turbulence usually cause rise in oxygen level. Lower value $(7.90 \mathrm{mg} / \mathrm{l})$ of D.O. was recorded during monsoon months due to low oxygen retention capacity of water with the rise in temperature and higher TDS status was also noticed by Badola and Singh (1981). The B.O.D. was recorded maximum $(3.40 \mathrm{mg} / \mathrm{l})$ during winter and minimum $(2.21 \mathrm{mg} / \mathrm{l})$ in summer months. Free $\mathrm{CO}_{2}$ was observed maximum (3.30 $\mathrm{mg} / \mathrm{l}$ ) in monsoon and low value was recorded in winter season. Pahwa and Mehrotra (1966) have reported that the Ganga river contains maximum free carbon dioxide in rainy season at Allahabad. Sulphate concentration was found to be maximum $(2.60 \mathrm{mg} / \mathrm{l})$ in summer season and lowest in monsoon $(1.27 \mathrm{mg} / \mathrm{l})$. Maximum value of chloride $(26.36 \mathrm{mg} / \mathrm{l})$ was recorded during summer and minimum (17.24 mg/l) during winter. The term alkalinity is defined as the quality of loss in water which reacts to neutralize hydrogen ions. The maximum value of alkalinity was found in summer $(160.61 \mathrm{mg} / \mathrm{l})$ and minimum in monsoon $(140.21 \mathrm{mg} / \mathrm{l})$. The cause of increasing alkalinity was the decomposition of the organic water.

\section{Acknowledgement}

The author express sincere thanks to Principal, Dr. A.K. Saxena, D.A.V. (P.G.) College, Dehradun and Head, Department of Zoology and Department of Chemistry for Laboratory facilities.

\section{References}

APHA AWWA WPCF (1998). Standard Methods for the Examination of Water and Wastewater. 20th Edition, American Public Health Association, 1015, Fifteen Street, New Washington DC, $15: 1-1134$.

Badola S.P. and Singh H.R. (1981). Hydrobiology of river Alaknanda of the Garhwal Himalaya, Indian J. Ecol., 8(2) : 269-276.

Baltish SK (1992). Freshwater Zooplankton of India. Oxford and IBM Publications.

Chauhan R (1993). Seasonal fluctuation of Zooplanktons in Renuka lake, Himanchal Pradesh. Uttar Pradesh J. Zool., 111(1) : 17-20.

Dede AN, AL Deshmukh (2015). Seasonal Variation of Zooplankton in Bhima River near Machnur Village, Dist: Solapur, (Maharashtra). GJRA, 4(2), 194-195 
Uttarakhand. Environment. Conser. J. 8(3) : 117-126.

on the Rotifera. Indian Association of Aquatic Biologist Hyderabad : 178.

Gannon JE, Stemberger RS (1978). Zooplankton (Especially Crustaceans and Rotifers) as Indicators of Water Quality. Trans. Am. Micros. Soc., 97 : 16-35.

Ishaq F, Khan A (2013). Assessment of Ecological Aspects and Impact of Pollution on Limnological conditions of River Yamuna in Uttarakhand India. European Journal of Experimental Biology,3(2):1831.

Joshi B D, Bisht R C S (1993). Some aspect of Physico-chemical characteristics of Western Ganga canal near Jwalapur at Haridwar. Him. J. Env. Zoo., 7(1) : 76-82.

Kaushal DK, Sharma VK (2007). Limnology and productivity of selected reservoirs of Eastern Rajasthan. In Proceedings of DAEBRNS, National Symposium on Limnology.

Khanna DR (1993). Ecology and Pollution of Ganga River. Ashish Publication House, Delhi, 1-21.

Khanna DR, Bhutani R (2004). Water analysis ay a glance. ASEA Publication, 1-115.

Khanna, D.R., Vikas Singh, R. Bhutani, Satish Chandra, Gagan Malta and Deeraj Kumar (2007). A Study of biotic and abiotic factors of Song river at Dehradun,
Kumar KS (2001). The freshwater zooplankton of some lakes in Dharmapuri district, Tamil Nadu. Journal of Aquatic Biology, 16: 5-10.

Mahajan CL (1981). Zooplankton as indicators for assessment of water pollution. Poll. Cent. Bd. Prev. Cont. Poll/Osm.Uni. Hyderabad, India.

Pahwa DV, Mehrotra SM (1966) “Observations on fluctuations in the abundance of plankton in relation to certain hydrobiological conditions of the river Ganga. Proc. nat. Acad. Sci. India, 36 B(2) : 157-159.

Pandey BN , Kumar K, Lala A, Das PKL (1993). A preliminary Study on the physico - chemical quality of water of the river Kosi. J. Ecobiol., 5 : 337-339.

Pandey BN, Hussain, Jha A.K., Shyamanand (2004).Seasonal fluctuation of zooplanktonic community in relation to certain parameters of river Ramjan of Kishanganj, Bihar. Nature Env. and Poll. Tech., 3(3) : 325-330.

Ramakrishna S (2014). Zooplankton seasonal abundance in relation to physico-chemical feature in Yelahanka lake, Bangalore. G.J.R.A., 3(6) : 218-219. 
Sinha RK (1992). Rotifer population of Ganga near Patna, Bihar, India. Proc. Nat. Acad. Sci ., India, 62(B): 313-322.

Sunkad BN, Patil HS (2004): Water quality assessment of fort lake of Belgaum (Karnataka) with special reference to zooplankton. J.Environ.Biol. ,25(1): 99102. 